\title{
Tyrosine-Protein Kinase Hck
}

National Cancer Institute

\section{Source}

National Cancer Institute. Tyrosine-Protein Kinase Hck. NCI Thesaurus. Code C18558.

Tyrosine-protein kinase Hck (526 aa, $\sim 60 \mathrm{kDa}$ ) is encoded by the human HCK gene. This protein plays a role in tyrosine phosphorylation, signaling and the regulation of innate immunity. 